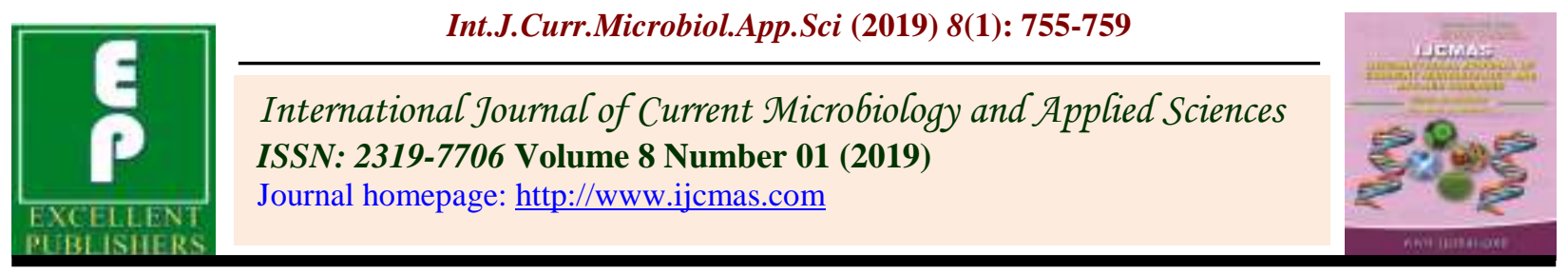

Original Research Article

https://doi.org/10.20546/ijcmas.2019.801.083

\title{
Use of Information Media and Awareness Status Regarding Dairy Animal Welfare Practices in Jamtara District of Jharkhand, India
}

\author{
Bhushan Kumar Singh ${ }^{1 *}$, J. Oraon ${ }^{2}$, Alok Kumar Pandey ${ }^{1}$, \\ Nandani Kumari ${ }^{3}$ and Kumari Shweta ${ }^{4}$
}

${ }^{1}$ Department of Veterinary and Animal Husbandry Extension Education, ${ }^{3}$ Department of Animal Breeding and Genetics, R.V.C., B. A. U., Kanke, Jharkhand, India

${ }^{2}$ Director Extension Education, Birsa Agricultural University, Kanke, Jharkhand, India

${ }^{4}$ Department of Veterinary and A. H. Extension, C. V.Sc. \& A. H., O. U. A. T., Bhubaneswar, Odisha, India

*Corresponding author

\section{A B S T R A C T}

Keywords

Information, Media and awareness,

Status,

Dairy animal Welfare practices

\section{Article Info}

Accepted:

07 December 2018

Available Online:

10 January 2019
The present paper is a descriptive study on use of information media and awareness status regarding dairy animal welfare practices in jamtara district of Jharkhand. Jamtara district has 6 blocks andto have a complete study of whole district, all the 6 blocks were selected. From the selected blocks, two villages (one Peri urban and one rural village) were selected randomly. Data were collected through structured interview schedule. Study revealed that majority of respondents (above 75 per cent) were aware regarding all the basic freedoms of the animals in both areas and the same per cent of dairy farmers believe that they are responsible for animal welfare on their own. Mostly information media contact for the awareness was found low for the 86.67 per cent respondents of rural \& 73.34 per cent respondents of peri urban areas.

\section{Introduction}

Information and Communication is very important in agriculture and animal husbandry. Ever since people have grown crops, raised livestock and caught fishes, they have sought information from one another. The last three decades has witnessed a dramatic increase in society's interest in the welfare of farm and other domesticated animals (Fraser, 2001; Levy, 2004) with the welfare of farm animals high on the political and societal agendas. Next to widespread public concerns about animal welfare (Serpell, 1999; Mejdell, 2006) its importance is acknowledged by all stakeholders along the animal production chain (Bracke et al., 2005).Understanding how different actors perceive animal welfare is a precondition for the successful improvement of welfare 
(Kauppinen et al., 2010). Therefore, the objective of this study was to gauze the farmers' information media exposure and awareness regarding dairy animal welfare practices.

\section{Materials and Methods}

Present study was carried out in purposively selected Jamtara district of Jharkhand. Jamtara district of Jharkhand was selected due to high population density of dairy animals with respect to land also it had peculiarity that it having highest male cattle density (NSSO, $59^{\text {th }}$ Round, land and livestock survey) which are more neglected in following welfare practice. Selected Jamtara district has total 6 blocks namely Jamtara, Kundhit, Nala, Narayanpur, Karmatanr, Fatehpur. To have a complete study of whole district, all the 6 blocks were selected. From the selected blocks two villages (one Peri urban and one rural village) were selected randomly. From each village ten livestock owners who had two or more than two dairy animals like cattle and buffalo was selected randomly. Therefore total sample size of the study was 120 respondents. In order to measure various dimension of the study, structured interview schedule was developed by incorporating available scales/measures and was used for data collection. It was measured on a four point continuum viz., frequently, often, seldom, never with respective score of $3,2,1$, and 0 .The respondents were categorized by using the range as:

Low information media exposure - score up to 3

Medium information media exposure - score more than 3 to 8

High information media exposure - score above 8

In order to get logical interpretation, the data was compiled, tabulated and statistical tools used were frequency, mean, median and Chisqure test as per Snedecor and Cochran (2004).

\section{Results and Discussion}

Information media exposures are the quickest means to spread the information to a large number of people in the shortest time. It plays very significant role in creating awareness and interest regarding improved technologies among the people. The distribution of respondents according to information media exposure is depicted in Table 1 . It revealed that majority of the respondents $(86.66 \%)$ of rural areas fell in low information media exposure and rest $(13.33 \%)$ respondents in medium exposure of information media. Whereas, in case of peri urban areas majority of the respondents (73.34\%) fell in low information media exposure followed by 20 per cent respondents in medium information media exposure and rest $(6.66 \%)$ in high information media exposure.

Pooled data showed that most $(80 \%)$ were fell in in low information media exposure followed by 16.67 per cent respondents in medium information media exposure and rest (3.33\%) in high information media exposure. Variation between both the area was nonsignificant. From the pooled data overall ranking of used information media, as shown in table 2 shows that majority of the dairy farmers were regularly obtaining relevant information from television by viewing farm telecast (ranked I) followed by dairy/krishimela (II) and awareness campaigns (III). The possible reason may be that, in present days television has become more of a necessity rather than a luxury.

As the majority of the respondents did not possess higher level of education, they had no choice except to viewing farm telecast for obtaining related information. Newspaper, 
radio, magazine and bulletins were ranked IV, $\mathrm{V}$ and VI, respectively. Result is in line with that of Pandey (1996) and Seth (2004) who reported that the mass media exposure still had the lowest penetration in their study area in Jharkhand.

Table 3 reflects the distribution of respondents according to the awareness about dairy animal welfare practices. As five freedoms were concerned, 100 per cent of respondents of both the areas were aware that animal should have freedom from the thirst and hunger, about the freedom from injury and disease, 91.66 per cent in rural and 93.33 per cent in peri urban were aware.
About the freedom from pain and discomfort, 85 per cent in rural and 86.66 per cent in peri urban were aware. 76.66 per cent and 80 per cent of respondents in rural and peri urban areas respectively were aware that animals should have freedom to express normal behavior. On the parameter animal should be free from fear and distress; 71.66 per cent and 80 per cent, animal should have enough space to move; 76.66 per cent and 86.66 per cent, animal should feel calm during handling; 91.66 per cent and 86.66 per cent, animal require good care on ethical ground; 76.66 per cent and 86.66 per cent respondents, respectively in rural and peri urban areas were aware.

Table.1 Distribution of respondents according to Information media contact

\begin{tabular}{|c|c|c|c|c|c|c|}
\hline $\begin{array}{c}\text { Information media } \\
\text { contact }\end{array}$ & \multicolumn{2}{|c|}{ Rural } & \multicolumn{2}{|c|}{ Peri urban } & \multicolumn{2}{c|}{ Pooled } \\
\cline { 2 - 7 } & $\begin{array}{c}\text { No. of } \\
\text { respondents }\end{array}$ & $\%$ & $\begin{array}{c}\text { No. of } \\
\text { respondents }\end{array}$ & $\%$ & $\begin{array}{c}\text { No. of } \\
\text { respondents }\end{array}$ & $\%$ \\
\hline $\begin{array}{c}\text { Low } \\
\text { (up to 3 score) }\end{array}$ & 52 & 86.67 & 44 & 73.34 & 96 & 80 \\
\hline $\begin{array}{c}\text { Medium } \\
\text { (3-8 score) }\end{array}$ & 8 & 13.33 & 12 & 20 & 20 & 16.67 \\
\hline $\begin{array}{c}\text { High } \\
\text { (8 \& above score) }\end{array}$ & 0 & 0 & 4 & 6.66 & 4 & 3.33 \\
\hline Total & 60 & 100 & 60 & 100 & 120 & 100 \\
\hline
\end{tabular}

Overall chi-square value: $5.466^{\mathrm{N}}$

Table.2 Distribution of respondents according to their mass media exposure

\begin{tabular}{|c|c|c|c|c|c|c|}
\hline Mass media & Regularly & Occasionally & Rarely & Never & Score & Rank \\
\hline Newspaper & 30 & 32 & 7 & 51 & 161 & IV \\
& $(24.00)$ & $(26.66)$ & $(5.83)$ & $(42.50)$ & & \\
\hline Radio & 4 & 9 & 12 & 95 & 42 & V \\
& $(3.33)$ & $(7.50)$ & $(10.00)$ & $(79.14)$ & & \\
\hline Television & 20 & 57 & 12 & 31 & 186 & I \\
\hline Magazine, bulletins & $(16.66)$ & $(47.50)$ & $(10.00)$ & $(25.84)$ & & \\
& 7 & 4 & 7 & 204 & 36 & VI \\
\hline Awareness campaigns & $(5.83)$ & $(3.34)$ & $(5.83)$ & $(85.00)$ & & \\
\hline & 27 & 29 & 26 & 38 & 165 & III \\
\hline Dairy/Krishimela & $(22.50)$ & $(24.17)$ & $(21.66)$ & $(31.67)$ & & \\
& 27 & 34 & 30 & 29 & 179 & II \\
\hline
\end{tabular}

Figures in parenthesis indicate percentage 
Table.3 Distribution of respondents according to the awareness about dairy animal welfare

\begin{tabular}{|c|c|c|c|c|c|c|}
\hline \multirow[t]{2}{*}{ Awareness regarding } & \multicolumn{2}{|c|}{$\begin{array}{l}\text { Rural } \\
(n=60)\end{array}$} & \multicolumn{2}{|c|}{$\begin{array}{c}\text { Peri urban } \\
(n=60)\end{array}$} & \multicolumn{2}{|c|}{$\begin{array}{c}\text { Pooled } \\
(\mathrm{N}=120)\end{array}$} \\
\hline & No. & $\%$ & No. & $\%$ & No. & $\%$ \\
\hline Freedom from thirst & 60 & 100 & 60 & 100 & 120 & 100 \\
\hline Freedom from hunger & 60 & 100 & 60 & 100 & 120 & 100 \\
\hline Freedom from injury \& disease & 55 & 91.66 & 56 & 93.33 & 111 & 92.50 \\
\hline $\begin{array}{c}\text { Freedom from pain } \& \\
\text { discomfort }\end{array}$ & 51 & 85.00 & 52 & 86.66 & 103 & 85.83 \\
\hline $\begin{array}{c}\text { Freedom to express normal } \\
\text { behaviour }\end{array}$ & 46 & 76.66 & 48 & 80.00 & 94 & 78.33 \\
\hline Free from fear \& distress & 43 & 71.66 & 48 & 80.00 & 91 & 75.83 \\
\hline Enough space to move & 46 & 76.66 & 52 & 86.66 & 98 & 81.66 \\
\hline Feel calm during handling & 55 & 91.66 & 52 & 86.66 & 107 & 89.16 \\
\hline Good care on ethical ground & 46 & 76.66 & 52 & 86.66 & 98 & 81.66 \\
\hline $\begin{array}{l}\text { Welfare agency like } \\
\text { SPCA/PETA/PFA }\end{array}$ & 2 & 3.33 & 7 & 11.66 & 9 & 7.50 \\
\hline \multicolumn{7}{|l|}{ Responsible agent for welfare:- } \\
\hline your self & 47 & 78.33 & 52 & 86.66 & 99 & 82.50 \\
\hline Veterinary doctor & 10 & 16.66 & 4 & 6.66 & 14 & 11.66 \\
\hline Government & 3 & 5 & 4 & 6.66 & 7 & 5.83 \\
\hline
\end{tabular}

Only 3.33 per cent in rural and 11.66 per cent in peri urban areas were aware about working agency (SPCA/PETA/PFA) for animal welfare. Regarding responsibility of welfare of animal, majority $(78.33 \%)$ of the respondents in rural areas and 86.66 per cent in peri urban believed that respondents themselves were responsible, followed by 16.66 per cent who believed that veterinarian and 5 per cent respondents of rural areas believed that government is responsible for animal welfare measures; whereas in peri urban 6.66 per cent believed that veterinarian and same per cent of respondents believed that government is responsible for animal welfare. The pooled value regarding the awareness of the respondents about dairy animal welfare showed that hundred per cent for freedom from thirst and hunger, 92.50 per cent for freedom from injury and disease,
85.83 per cent for freedom from pain and discomfort, 78.33 per cent for freedom to express normal behavior, 75.83 per cent for free from fear and distress, 81.66 per cent for enough space to move, 89.16 per cent for feel calm during handling, 81.66 per cent for good care on ethical ground. Only 7.50 per cent of respondents were aware about welfare agencies. Regarding responsible agent for welfare, majority $(82.50 \%)$ believed on himself, 11.66 per cent to veterinary doctor, 5.83 per cent to government agency. Over all chi-square values for all the parameters of awareness shows non-significant difference in between the respondents of rural and peri urban areas. Results are in agreement with the findings of Kumar (2008), who finds that generally farmers were aware about some basic aspects of animal welfare. 
In conclusion, generally dairy farmers were aware about some basic aspect of animal welfare like different component of "Five Freedoms" viz. freedom from pain, injury, disease; freedom from hunger and thirst; freedom from discomfort; freedom from fear and distress and freedom to express normal behaviour. Dairy farmers knew these freedom on ethical ground. But the use of information media still had the lower penetration in the study area, due to which they had poor knowledge about the modern dairy farming techniques, so it is important to develop information centers in their locality.

\section{References}

Bracke, M.B., Greef, M.K. and Hopster, H. (2005). Qualitative stakeholder analysis for the development of sustainable monitoring systems for farm animal welfare. J. Agric. Environ. Ethics 18: 27-56.

Fraser, D. (2001). Farm animal production: changing agriculture in a changing culture. J. Appl. Anim. Welf. Sci. 4: 175-190.

Kauppinen, T., Vainio, A., Valros, A., Rita, H. and Vesala, K.M. (2010). Improving animal welfare: qualitative and quantitative methodology in the study of farmer's attitudes. Anim. Welfare, 19(4): 523-536.

Kumar, V. (2008). Farm animal welfare practices in madhubani district of bihar. M.V.Sc. thesis, IVRI, Izatnagar.
Levy, N. (2004). What Makes Us Moral? Crossing the Boundaries of Biology. One World. Oxford, UK. Mejdell, C.M. (2006). The role of councils on animal ethics in assessing acceptable welfare standards in agriculture. Livest. Sci. 103: 292-296.

Mejdell, C. M. (2006). The role of councils on animal ethics in assessing acceptable welfare standards in agriculture. Livestock Science, 103(3), 292-296.

Pandey, A.K. (1996). A comparative study of livestock rearing system among tribals and non tribals in chotanagpur region of Bihar. Ph.D. Thesis, NDRI, Karnal.

Prevention of Cruelty to Animals Act (1960). The Prevention of Cruelty to Animals Act (59 of 1960). As amended by Central Act 26 of 1982. Available at: www.envfor.nic.in/legis/awbi/awbi01. html.

Snedecor, G.W. and Cochran, W.G. (2004). Statistical method, oxford \& IBH, publishing company, New Delhi.

Seth, P. (2004). Problems and prospects of Dairy cooperatives in Jharkhand. M.V.Sc. Thesis, Birsa Agricultural University, Ranchi.

Serpell, J. (1999). Sheep in Wolves' Clothing? Attitudes to Animals among Farmers and Scientists. In: Attitudes to Animals: Views in Animal Welfare. F.L. Dolins (edt.) Cambridge University Press, Cambridge, UK.

\section{How to cite this article:}

Bhushan Kumar Singh, J. Oraon, Alok Kumar Pandey, Nandani Kumari and Kumari Shweta. 2019. Use of Information Media and Awareness Status Regarding Dairy Animal Welfare Practices in Jamtara District of Jharkhand, India. Int.J.Curr.Microbiol.App.Sci. 8(01): 755-759. doi: https://doi.org/10.20546/ijcmas.2019.801.083 